\title{
DATA SEMENTARA BANGUNAN KOMPLEKS PENDAPA KRATON RATU BAKA
}

\author{
Oleh : Slamet Pinardi
}

\section{PENGANTAR.}

\section{A. U m u m.}

Dalam rangka pemugaran kompleks Pendapa Kraton Ratu Baka, perlu diadakan pengamatan serta penelitian secara khusus pada setiap gejala serta data yang muncul. Pengamatan serta penelitian tersebut dilakukan sebelum maupun selama pemugaran berlangsung. Secara keseluruhan, kompleks pendapa tersebut terletak di bagian tenggara kompleks kekunaan Ratu Baka.

Pemugaran kompleks Pendapa Kraton Ratu Baka yang dilakukan oleh Proyek Pemugaran dan Pemeliharaan Peninggalan Sejarah dan Purbakala DIY telah berlangsung sejak tahun 1979 hingga saat ini. Pada kesempatan ini, penulis diberi kesempatan sebagai staf proyek, sehingga dapat melakukan pengamatan dan penelitian secara arkeologis selama pemugaran berlangsung. Oleh karena itu, penulis ingin mengucapkan rasa terima kasih kepada Drs. Th. Aq. Sunarto selaku Kepala Suaka Peninggalan Sejarah dan Purbakala sekaligus Pemimpin Proyek Pemugaran dan Pemcliharaan Peninggalan Sejarah dan Purbakala D.l.Y. yang telah memberi kesempatan kepada penulis untuk ikut aktif dalam kegiatan pemugaran. Tambahan data yang berupa data bangunan tersebut diharapkan akan da. pat memperjelas peranan kompleks kekuanaan Kraton Ratu Baka di masa silam, dan dapat memperlebar jangkuan interpretasi arkeologi Klasik, khususnya yang terletak di kawasan tersebut.

\section{B. Riwayat Penelitian.}

Penelitian terhadap kompleks Kraton Ratu Baka telah banyak dilakukan oleh beberapa akhli. Berita tertua mengenai peninggalan ini diperoleh dari catatan Van Boeckholtsz tahun 1790, yang menyebutkan bahwa dataran tinggi ini "pernah didiami oleh seorang raja". Awal penelitian di Kraton Ratu Baka telah dimulai pada tahun 1938, meskipun dalam tahuntahun berikutnya mengalami penghentian. Penggalian arkeologis baru dilaksanakan dalam tahun 1950, yaitu di dekat batur pendapa besar ( $\mathrm{A}$ merta I. 1952: 48).

Dalam Laporan Tahunan Dinas Purbakala RI, disebutkan bahwa telah ditemukan sebuah batur persegi panjang yang terletak di sebelah timur batur pendapa besar. Batur tersebut berukuran $36.12 \times 5.85 \times 1.08$ meter. dengan orientasi utara-selatan. Pada permukaan lantai batur tersebut ter- 
dapat alur-alur yang menunjukkan adanya tembok keliling setebal $\pm 32 \mathrm{~cm}$ vang pada sisi-sisi panjangnya diperkuat dengan 10 buah tiang (termasuk tiang-tiang sudut) setebal $45 \times 40 \mathrm{~cm}$. Mungkin sekali batur ini mempunyai 4 bilik yang dibatasi oleh tembok-tembok setebal $\pm 23 \mathrm{~cm}$. Setiap bilik mempunyai tangga di sisi baratnya. kecuali bilik paling selatan. Bilik selatan ini dihubungkan oleh sebuah pintu dengan bilik di utaranya.

Di samping itu, dari penggalian yang dilakukan telah ditemukan fraymen dua buah periuk dari tanah. Satu di antaranya ditemukan dari sebelah timur laut batur pada kedalaman $60 \mathrm{~cm}$. Di dekat periuk tersebut ditemukan sebuah batu akik, sehelai lempengan perunggu berlapis perak dan schelai lempengan emas. Kedua lempengan logam tersetut memuat beberapa tulisan (Dinas Purbakalá RI, 1958 : 18).

Berdasarkan laporan bulanan Dinas Purbakala RI (Juni, 1954), disebutkan bahwa di bagian utara batur pendapa terdapat timbunan tanah dan batu-batu. Rekonstruksi batu-batu tersebut telah menghasilkan sebuah gapura. Demikian pula dari batu-batu yang berasal dari sisi barat batur pendapa, telah menghasilkan suatu rekonstruksi yang merupak-an tembok tiang pintu suatu gapura.

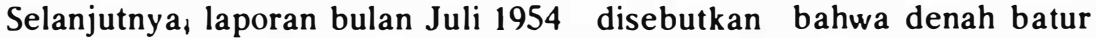
berbentuk bujur sangkar dengan tinggi sekitar 1,43 meter. Di sebelah selatan batur pendapa terdapat sebuah batur lainnya yang berdenah empat persegi panjang, yang masih tertimbun tanah. Batur dengan denah persegi panjang mempunyai ukuran lebar 7 meter, dan panjangnya sama dengan panjang batur pendapa, dengan jarak antara kedua batur tersebut 2,50 meter. Antara dua batur tersebut dihubungkan dengan batur terusan yang lebarnya $\pm 1,90$ meter. Batur terusan ini mempunyai tangga di sisi barat dan timur. Kedua batur tersebut dikelilingi oleh pagar batu berangkai dengan selasar mengelilingi batur, yang semula tertutup tanah dan batu-batu runtuhan pagar keliling. Pengamatan terhadap batur pendapa telah menunjukkan adanya tiga buah tangga, yaitu pada pertengahan sisi barat, utara dan timur. Ketiga tangga tersebut tidak berkaitan, tetapi hanya menempel pada dinding batur pendapa. Letak ketiga tangga tersebut masih dapat ditentukan, karena adanya data yang berupa bekas goresan tatah pada dinding batur. Tentunya, goresan tersebut merupakan bekas pahatan halus pada saat dilakukan pemasangan ketiga tangga tersebut.

Pada saat dilakukan penyingkiran tanah penutup selasar, telah ditemukan sebagai berikut :

\section{Fragmen prasesti.}

a. Fragmen prasasti ditemukan di bagian selasar timur, pada jarak sekitar 1,50 meter ke arah timur dari tengah sisi timur pendapa. Pecahan prasasti tersebut dapat disambung dengan pecahan prasasti sejenis yang sudah ditemukan terlebih dahulu. Berdasarkan hasil rekonstruksi tersebut, diketahui bahwa masih ada bagian prasasti yang belum ditemukan (lihat foto dokumentasi Dinas Purbakala RI 1954 No. 1856 sampai dengan $1860)$. 
b. Fragmen prasasti lain yang berbeda huruf dengan fragmen prasasti di atas.

Fragmen ini ditemukan \pm 7 meter dari sudut tenggara batur pendapa ke arah barat dan \pm 1,5 meter ke arah selatan (foto dokumentasi No. 1861).

\section{Arca garuda bertubuh manusia.}

Arca ini duduk di atas padmàsana, dengan ukuran arca sebagai berikut : tinggi $77 \mathrm{~cm}$, lebar $37 \mathrm{~cm}$ dan tebal $37 \mathrm{~cm}$. Bagian paruhnya telah rusak. Lokasi penemuan berada sekitar 6 meter di sebelah barat sudut timur laut dan 1 meter di sebelah utara batur pendapa (foto dokumentasi No. 1862 sampai dengan 1864).

\section{Sebuah mangkuk porselln.}

Ditemukan masih utuh dan berisi tanah, tanpa tutup. Lokasi penemuan berada sekitar 3,50 meter di sebelah barat sudut tenggara batur persegi panjang (foto dokumentasi No. 1865 dan 1866).

Dalam laporan bulan September 1954, disebutkan penemuan batu-batu yang berasal dari batur di sebelah timur pagar pendapa, pagar keliling pendapa, bagian gapura pendapa sisi utara, selatan dan barat, serta sejumlah besar batu yang belum diketahui tempatnya. Selanjutnya, dalam laporan bulan Oktober 1954 disebutkan pula penemuan fragmen prasasti yang dalam peta penggalian saat itu termasuk dalam kotak G XI. Pecahan prasasti ini masih belum dapat disambung. Dengan demikian, telah ditemukan 4 buah fragmen prasasti. Tiga buah di antaranya merupakan fragmen terpisah, sedangkan sebuah telah lengkap disambungkan dengan bagian lainnya.

Penemuan lainnya adalah sebuah peti batu dari batu putih, yang berasal dari scbelah timur pagar keliling, pada kedalaman $10 \mathrm{~cm}$ di bawah permukaan tanah. Temuan tersebut termuat dalam laporan bulan Juli 1958 . Tutup peti batu tersebut telah terbuka, dan diketahui adanya sebuah lubang persegi di bagian dalamnya. Seluruh penemuan di atas merupakan suatu persoalan yang menunggu pemecahan lebih lanjut mengenai hubungannya dengan bangunan kompleks Ratu Baka secara menyeluruh.

Setelah cukup lama tidak tersentuh oleh para arkeolog, akhirnya pada tahun 1973 telah dilakukan ekskavasi di beberapa tempat dalam kompleks Kratoin Ratu Baka. Ekskavasi ini merupakan bagian dari program latihan untuk para arkeolog muda Indonesia, yang diselenggarakan atas kerja sama antara Lembaga Purbakala dan Peninggalan Nasional, Universitas Indonesia, Universitas Gadjah Mada, Universitas Udayana dan University. of Pennsilvania. Dengan demikian, penelitian tersebut mempunyai tujuan ganda, yaitu suatu bentuk penelitian yang sckaligus diarahkan pada lingkup pendidikan dan latihan. 
Penelitian tersebut dapat dianggap sebagai suatu kemajuan yang telah dicapai ke arah penentuan suatu kronologi artefak untuk kompleks Ratu Baka serta situs-situs di sekitarnya, meskipun belum dapat memberikan gambaran yang lebih jelas mengenai fungsi kekunaan Kraton Ratu Baka. Metode baru yang dipakai, misalnya ekskavasi stratigrafis dan analisis sistematis dari temuan-temuan kecil, merupakan metode baru bagi pene. litian arkeologi klasik di Indonesia (Teguh Asmar-Bennet Bronson, 1973 : 56). Oleh karena itu, temuan ekskavasi yang dilakukan di antara pagar timur pendapa dan balai-balai, dianggap kurang berarti karena stratigrafinya sudah sangat terganggu. Hal ini mungkin disebabkan oleh teraduknya tanah di tempat tersebut di saat dilakukan pemugaran balaibalai pada tahun $1953-1954$.

\section{DATA KEgIATAN PEMUGARAN.}

\section{A. Kegiatan Sebelum Pemugaran.}

Selama tahun 1978, kegiatan pemugaran ditujukan untuk pengamatan serta pencarian batu-batu gapura dan pagar keliling. Lebih kurang 25 meter di sebelah selatan pagar selatan, terdapat tumpukan batu, yang pada masa sebelumnya pernah ditemukə.n pula arca Durga berukuran tinggi $90 \mathrm{~cm}$, lebar $55 \mathrm{~cm}$ dan tebal $33 \mathrm{~cm}$ (lihat Laporan Tahunan Dinas Purbakala RI tahun 1954). Dari tumpukan batu ini antara lain berhasil ditemukan :

1. Fragmen arca manusia yang duduk di atas padmasana, dengan sikap duduk paryankasana. Arca ini hanya tinggal setengah bagian, yaitu bagian perut ke bawah, dengan ukuran tinggi keseluruhan $21 \mathrm{~cm}$, tinggi $11 \mathrm{~cm}$. lebar keseluruhan $19 \mathrm{~cm}$, lebar arca $18 \mathrm{~cm}$ dan diameter lubang $9.5 \mathrm{~cm}$. Tangan kanan arca terletak di atas lutut kanan, dengan posisi tengadah sambil menggenggam suatu bulatan. Sikap tangan kiri tidak diketahui karena telah rusak. Di bawah arca terdapat lubang yang berbentuk setengah bola dengan haisan daun bunga padma bertumpuk, sedangkan lengan dan kakinya dihiasi dengan gelang (?). Lubang pada arca tersebut biasanya merupakan pancuran (jaladvara). Karena arca ini sudah tidak lengkap lagi, maka sulit untuk diketahui identitasnya.

2. Scjumlah besar batu-batu yang berasal dari bagian atas pagar keliling serta batu-batu gapura.

Setelah dilakukan susunan percobaan, ternyata batu-batu tersebut merupakan atap pagar keliling yang terdiri dari tiga bagian, yaitu bagian bawah senlatiam imbang (dorpel), bagian tengah berbentuk seperti padma (payon . dan bagian puncak yang berbentuk seperti buah keben (mercu). Setclah dicoba dipasangkan di atas pagar yang ada sekarang. tornyata 
bagian atas tersebut tidak cocok. Tubuh pagar keliling terdiri atas empat susun batu andesit dan di permukaannya terdapat pen (takik) untuk pengait batu di atasnya. Hal ini menimbulkan dugaan bahwa di atas pagar keliling yang empat lapis tersebut tentunya masih ada beberapa batu lagi, baru kemudian batu atap di atasnya.

3. Temuan batu-batu putih, yang diduga merupakan tubuh gapura barat bagian sudut utara di ujung timur. Setelah dicoba dipasangkan, batu-batu pagar cocok dengan batu putih tersebut, sehingga dapat diperoleh satu contoh susunan pagar keliling yang terdiri dari tiga bagian, yaitu tubuh pagar yang terdiri dari empat lapis batu andesit dan tiga lapis batu putih, kemudian diatasnya batu-batu atap yang terdiri atas tiga bagian pula. Dan inilah yang memungkinkan dapat dipugarnya pagar keliling serta gapura-gapuranya.

Dari pengamatan yang telah dilakukan, diperoleh data yang berupa: - Lantai (selasar) pendapa terdiri dari dua bagian. Bagian pertama merupakan lantai yang lurus atau membentuk garis lurus yang mengitari ketiga sisi batur pendapa (sisi utara, timur dan barat). Sedang sisanya hingga pagar keliling terdiri dari susunan batu yang tidak membentuk garis lurus. Kedua data ini menarik sekali karena dapat menimbulkan pertanyaan mengapa lantai tersebut terdiri dari dua bagian. Pertanyaan ini akhirnya terjawab pula setelah diadakan pembongkaran dan pemugagaran lantai. Lanti pertama yang membentuk garis lurus, masingmasing ukurannya adalah :

$280 \mathrm{~cm}$ ke arah barat dari dinding batur pendapa sisi barat

$220 \mathrm{~cm}$ ke arah utara dari dinding batur pendapa sisi utara

$270 \mathrm{~cm}$ ke timur dari dinding batur pendapa sisi timur

- Di luar pagar keliling sisi selatan, yaitu di bagian tenggara terdapat susunan lantai. Lantai ini sejajar dengan lantai di sebelah dalam pagar keliling. Akan tetapi di atasnya masih terdapat lantai batu andesit dan batu putih. Pada lantai di luar pagar tersebut, setiap $\pm 115 \cdot 120 \mathrm{~cm}$ membujur ke barat, terdapat umpak-umpak kecil dengan ukuran 23 × 23 $\mathrm{cm}$. Sayang sekali susunan lantai di selatan pagar keliling sisi selatan ini telah rusak, karena sebagian besar telah dibongkar di masa lalu.

- Sebagian besar batu payon (bagian atap pagar), pada alasnya semula diberi tonjolan (takik) sebagai pengait dengan batu di bawahnya, namun takik tersebut akhirnya dipotong hingga rata. Hal ini memberi kesan bahwa atas pertimbangan tertentu, pelaksanaan pekerjaan dapat berbeda dengan perencanaan pekerjaan. 
- Sejumlah tanda (goresan) pada batu-batu, jumlah dan variasi bentuk goresannya cukup banyak. Tanda-tanda tersebut belum dapat diketahui secara pasti arti dan maknanya. (gambar la dan lb.).

\section{B. Data Bangunan yang Diperoleh Selama Pemugaran.}

Dari hasil kegiatan pemugaran, diperoleh beberapa data bangunan yang selama ini belum pernah dijumpai di kompleks pendapa Kraton Ratu Baka. Data bangunan tersebut dapat diperinci menjadi 3 .

a. Fondasi bangunan dan kondisi tanah.

Oleh karena kegiatan pemugaran disertai dengan kegiatan pengamatan serta penelitian data arkeologis, maka setiap kegiatan yang berupa pembongkaran serta penggalian fondasi dilakukan secermat mungkin dan metodis. Areal sekitar pendapa merupakan areal tata letak (lay-out) seluas $90 \times 92$ meter. Hal ini dilakukan mengingat perlunya penelitian lanjutan yang berupa ekskavasi di masa mendatang.

Titik nol (datum point) berada 2 meter di utara sudut barat laut pagar keliling. Areal di utara pagar keliling sisi utara sebagian besar merupakan lapisan batu putih yang telah tampak beberapa bagian di permukaan tanah. Areal sekitar kompleks pendapa mempunyai ketinggian $+196,12$ meter di atas permukaan laut (lihat peta). Titik trianggulasinya terletak beberapa ratus meter ke arah timur laut pendapa.

Data fondasi yang diperoleh sebagai berikut : gapura-gapura serta pagar keliling hanya mempunyai satu lapis batu fondasi. Sedangkan lantai (selasar) yang mengelilingi pendapa terdiri dari dua bagian, yaitu bagian sekitar batur pendapa terdiri dari tiga lapis batu serta bagian yang dekat pagar keliling terdiri dari dua lapis batu.

Kondisi tanah penyangga bangunan kompleks pendapa berbeda di masing-masing tempat. Hal ini mengakibatkan beberapa bagian dari bangunan khususnya pagar keliling, melesak, mengalami penurunan dan runtuh. Data ekskavasi menunjukkan bahwa lapisan tanah di bawah gapura pagar dan lantai sebelah utara batur pendapa sebagian besar terdiri dari batu padas, sehingga bangunan di sisi ini relatif lebih stabil dari sisi lainnya. Diduga bahwa perencana bangunan kompleks pendapa Kraton Ratu Baka telah mempertimbangkan segi-segi teknis, terutama fondasi bangunannya. Hal ini dibuktikan dengan adanya lapisan fondasi yang cukup keras, yaitu terdiri dari semen merah setebal $5-10 \mathrm{~cm}$ di bagian paling atas, kemudian di bawahnya adalah lapisan kricak bercampur semen merah setebal $10-15 \mathrm{~cm}$, yang disusul dengan pecahan batu putih bercampur tanah liat, kemudian tanah liat dan lapisan batu padas pada bagian paling bawah. 
Pembongkaran fondasi gapura utara menunjukkan bahwa gapura tersebut berdiri di atas lapisan batu padas. Pada permukaan batu padas tersebut terdapat beberapa lubang yang sebagian besar berbentuk bulat. berdiameter $6-30 \mathrm{~cm}$. Kedalaman lubang tersebut berkisar antara $8-45$ $\mathrm{cm}$. Lubang-lubang tersebut terisi tanah, sedang lubang yang besar berisi pecahan batu putih dan kricak. Kemungkinan lubang-lubang tersebut merupakan lubang penyangga kayu perancah sewaktu pembangunan kompleks pendapa Kraton Ratu Baka berlangsung. .

\section{b. Perluasan pagar keliling.}

Setelah batu-batu lantai (selasar) lapis pertama dibongkar, ternyata terdapat bekas susunan pagar yang sangat jelas. Batu-batu pagar tersebut berada tepat dibawah permukaan lantai yang membentuk garis lurus. Dari data ini diperoleh bukti bahwa lantai dan pagar keliling pendapa di masa lampau telah mengalami perluasan (pelebaran). Batu-batu pagar tersebut mengelilingi batur pendapa, serta mempunyai lubanglubang pengait. Batu-batu yang merupakan permukaan lantai, bagian bawahnya tidak diberi pengait, meskipun batu dibawahnya mempunyai takik. Dari susunan batu bertakik (selanjutnya disebut pagar I) disisi barat terputus 2,08 meter dan diganti batu polos lima buah. Batu-batu polos ini tidak lurus dengan gapura barat, tetapi agak bergeser ke selatan Sedangkan di tengah-tengah batur pendapa, pada lantainya terdapat bekas tangga atau gapura menuju batur pendapa. Batu-batu pagar I sisi selatan berada di bawah banguan batur persegi panjang yang berada di selatan batur pendapa.

Dengan demikian, lebar lantai (selasar) semula adalah selebar lantai di atasnya yang membentuk garis lurus. Sedangkan lebar lantai sisi selatan paling lebar di antara ketiga sisi lainnya.

Suatu hal yang menarik adalah ukuran batu-batu pagar I sama dengan ukuran batu-batu pagar II. Hal ini menimbulkan dugaan bahwa batu-batu pagar II mungkin dahulunya merupakan batu-batu pagar I. Setelah diadakan perluasan, empat lapis batu pagar I dipindahkan menjadi tubuh pagar II.

Di samping itu, batu-batu lantai pagar I terdiri dari tiga lapisan batu, sedang batu-batu lantai pagar II terdiri dari dua lapis batu. Demikian juga lapisan tanah (fondasi) lantai pagar I dan pagar II sedikit berbcda. yaitu tidak terdapat lapisan semen merah pada fondasi pagar II. 


\section{c. Batur persegi panjang.}

Di muka telah disebutkan bahwa di selatan batur pendapa terdapat batur yang berdenah empat persegi panjang. Batur ini dihubungkan dengan batur pendapa melalui batur terusan yang lebarnya 1,90 meter dan panjangnya 2.50 meter. Di kanan kiri batur terusan terdapat tangga yang sempit. Ukuran batur persegi panjang tersebut adalah : lebar 7 meter dan panjangnya sama dengan panjang batur pendapa. Lantai bagian atas batur ini sebagian telah hilang, yang tampak hanyalah batu-batu isian, yaitu balokbalok batu putih. Namun demikian, beberapa batu lantainya serta batu bagian luarnya sebagian besar masih ada. Setelah diadakan percobaan, maka diperoleh petunjuk bahwa pada lantai batur persegi panjang terdapat umpak yang berupa tonjolan segi delapan pada setiap 2,50 meter. Ukuran dan bentuk umpak tersebut mirip sekali dengan umpak-umpak yang terdapat pada pantai batur pendapa. Untuk memastikan lantai hal ini perlu dilakukan pembuktian lebih lanjut, mengingat susunan percobaan lantai batur persegi panjang belum lengkap.

Setelah batur persegi panjang dibongkar seluruhnya, terdapat data lainnya sebagai pelengkap data bangunan sebelumnya. Data tersebut berupa susunan batu yang berukuran lebar 1,45 - 1,47 meter, dengan panjang 8,10 meter. Susunan batu tersebut lurus membujur utara-selatan dan lebih tinggi 12 - $15 \mathrm{~cm}$ dari lantai sekitarnya. Susunan batu tersebut merupakan jalan lurus (doorlop) yang menghubungkan batur pendapa dengan gapura selatan pagar keliling II. Ujung utara dari jalan lurus ini terdapat bekas-bekas tangga yang kemudian ditutup dengan batu-batu, sehingga menjadi batur terusan di atas. Sedang tangganya sendiri yang menghubungkan jalan lurus dengan batur pendapa digeser ke selatan menjadi tangga batur persegi panjang, berhadapan dengan gapura selatan pagar keliling. Dengan demikian terjadi tiga kali tahap pembangunan yang dilakukan dalam kompleks pendapa Kraton Ratu Baka. Data tersebut sangat menarik perhatian untuk dijadikan bahan penelitian lebih lanjut di samping data yang diperoleh di luar pagar.

\section{PENUTUP.}

Dari hasi ekskavasi yang dilakukan dalam tahun 1973, diperoleh suatu kesimpulan bahwa daerah Ratu Baka mempunya perjalanan sejarah yang cukup panjang, yang meliputi empat tahapan. Tahapan terscbut dapat dijabarkan sebagai berikut

Tahap I : tahun $600(?) / 700-775 / 825$ :

Dalam tahap ini. Ratu Baka hanya didiami sejumlah kecil penduduk dan terdiri dari beberapa pekerja bangunan, pelayan, serta beberapa orang tingkat atas. Tahap ini dimulai sebclum masa Jawa Tengah terbentuk, 
yang menuju ke masa di saat orang Jawa Tengah mendirikan bangunan batu beserta prasastinya. Sedangkan prasasti yang bersifat Buddhistis yang berangka tahun 792 Masehi dapat diduga pembuatannya pada akhir tahap ini. Mungkin sekali bangunan batı dan batu putih didirikan pada tahap I ini juga.

Tahap II : tahun 775/825 - 1025/1050.

Secara relatif dapat ditafsirkan bahwa penduduk Ratu Baka terdiri dari sejumlah besar para pekerja bangunan, tukang-tukang, pelayan-pelayan dan orang-orang tingkat atas. Mungkin juga terdapat pendeta-pendeta atau orang-orang terpandang yang bukan dari golongan beragama. Semua bangunan yang dibuat dari batu andesit di Ratu Baka, didirikan semasa awal dari tahap II, meskipun tampaknya bangunan-bangunan ini diteruskan sampai tahap III. Sebagian besar dari prasasti Ciwaistis juga dibuat dari masa-masa ini.

Tahap III : tahun 1025/1050 - 1350/1400 :

Pada tahap ini, daerah Ratu Baka diduduki oleh para petani, pemotong batu, tukang-tukang dan beberapa orang yang cukup berada untuk membeli porselin Cina. Meskipun tidak ada bangunan batu yang didirikan, juga tidak terdapat prasasti atau patung yang dibuat pada masa ini. Jumlah penduduk pada tahap ini tidak lebih kecil dari pada penduduk pada masa sekarang, yaitu sekitar 100 orang.

Tahap IV : tahun 1250/1400 - 1850/sekarang.

Sebelum tahun 1850, daerah ini sebagian besar kosong dan ditinggalkan pcnduduknya. Pada masa 1850 hingga kini, daerah ini didiami oleh para petani, pemotong batu putih dan pekerja-pekerja purbakala.

Berdasarkan kesimpulan-kesimpulan tersebut di atas, cukup menarik pcrhatian adalah mengenai bangunan-bangunan yang didirikan. Menurut kesimpulan tersebut, bangunan-bangunan dari batu mengawali bangunanbangunan daribatu putih ataupun dalam satu tahap juga.

Dari data bangunan yang ada sekarang. memang banyak dijumpai adanya bangunan dari batu andesit dan bangunan dari batu putih atau bangunan dari batu andesit dan batu putih. Begitu pula batur yang berdenah empat persegi panjang, batu isiannya juga dari batu putih. Dengan demikian dapatlah ditarik kesimpulan sementara dari data bangunan kompleks pendapa Kraton Ratu Baka yang diperoleh selama pemugaran berlangsung sebagai berikut 
1. Kompleks pendapa Kraton Ratu Baka mengalani tiga kali pembatngunan. yaitu pembangunan batur pendapa dengan pagar kcliling $\mathrm{l}$. perluassin pagar keliling hingga menjadi pagar keliling Il dan penambahan hatur yang berdenah persegi panjang sehingga mempersempit lantai sisi sclatan.

\section{a. Pembangunan batur pendapa dengan pagar $\mathbf{l}$.}

Kemungkinan sekali bahwa pagar I tidak terlalu tinggi, karena jaraknya terlalu dekat dengan batur pendapa. Oleh karena batu-batu atap tidak cocok bila dipasangkan di atas batu-batu pagar l (yang kemudian menjadi sebagian tubuh pagar Il), maka dugaan ini menjadi lebih beralasan. Mengingat bahwa pada susunan batu pagar I sisi barat terputus 2.08 meter dan diganti dengan batu-batu polos, serta lantainya menunjukkan adanya bekas-bekas tangga yang menuju ke batur pendapa, maka kemungkinan adanya tangga dari arah barat cukup beralasan. Sedang adanya gapura di sisi barat masih disangsikan meskipun tidak menutup kemungkinan adanya gapura tersebut. Sedangkan sisi utara dan timur tidak ditemukan adanya bekas-bekas tangga tersebut. Di sisi selatan terdapat tangga juga. Jika dibandingkan ukurannya, ternyata lantai (selasar) batur pendapa sisi selatan lebih luas dari lantai-lantai lainnya.

b. Perluasan pagar keliling.

Daridata yang tampak, jelas bahwa terjadi suatu perluasan dalam kompleks pendapa, khususnya lantai dan pagar keliling. Perluasan ini dilakukan dengan memindah tembok pagar keliling, tanpa membongkar fondasi pagarnya. Hal ini tampak setelah dilakukan pembongkaran lapisan lantai paling atas. Setelah lantai dan pagar keliling diperluas, maka diadakan penambahan (peninggian) tubuh pagarnya. Penambahan tersebut meliputi peninggian lantai dengan satu lapis batu, serta tubuh pagar dengan tiga lapis batu putih, kemudian atap pagarnya. Penambahan tubuh pagar dengan batu putih tidaklah mengherankan karena di kompleks Kraton Ratu Baku ini banyak dijumpai bangunan yang terdiri daribatu atau batu andesit dan batu putih. Mungkin atas pertimbangan tertentu, penambahan batu putih ini dilakukan. Pada saat perluasan ini pula, lantai selatan merupakan lantai yang terluas. bahkan di tengah-tengahnya terdapat jalan lurus yang menghubungkan batur pendapa dengan gapura selatan. Gapura-gapura utara, barat dan selatan merupakan tambahan pada saat dilakukan perluasan lantai dan pagarnya.

2. Kesimpulan kedua yang dapat ditarik dari data yang ada adalah : kumpleks kekunaan di Ratu Baka (khususnya kompleks pendapa) tidak 
hanya berfungsi pada satu masa tertentu, tetapi di masa-masa berikutnya juga masih dipakai, yang disesuaikan dengan kebutuhan-kcbutuhan sat itu, schingga mengalami beberapa kali pembangunan. Hal scperti ini terjadi pula pada bangunan-bangunan candi, misalnya Candi Kalasan dan lain-lain. Dengan demikian dapatlah ditegaskan bahwa dugaan yang menyatakan fungsi bangunan Kraton Ratu Baka sebagai benteng pertahanan terhadap serangan musuh, tidaklah benar. Hal ini didasarkan atas temuantemuan dari ekskavasi tahun 1973 serta data bangunan yang ditemukan saat ini. Meskipun demikian, suatu masalah masih menyelimuti kekunaan Ratu Baka ini, yaitu fungsi bangunan di masa lampau.

Setidak-tidaknya, dengan data yang ada sekarang ini dapat mengacu masalah fungsi bangunan yangı pernah dikemukakan oleh J. G. de Casparis tentang fungsi bangunan di Kraton Ratu Baka ini. Adakah bangunan ini menunjukkan vihara yang identik dengan bangunan Abhayagiri Vihara di Ceylon? Tentu saja semua ini memerlukan penelitian mendalam. Apabila dugaan tersebut benar, maka pada saat dahulu telah terjadi hubungan kebudayaan antara lndonesia dengan Ceylon.

3. Kesimpulan ketiga yang dapat ditarik adalah : penelitian terhadap kekunaan di Ratu Baka saat ini merupakan titik awal dari penelitian yang harus dilakukan, untuk memperoleh gambaran yang lebih jelas mengenai fungsi dan pernan kompleks kraton Ratu Baka di masa silam, sehingga dapat melengkapi kesenjangan-kesenjangan sejarah kebudayaan Indonesia di masa lalu.

Dari data yang ada membuktikan bahwa di luar pagar keliling kompleks pendapa ditemukan beberapa data, di antaranya terdapat susunan batu andesit yang kemungkinan merupakan pagar atau fondasi bangunan yang ditemukan dalam ekskavasi kotak C.33 spit (3) atau $115 \mathrm{~cm}$ di bawah per. mukaan tanah. Begitu juga dari ekskavasi yang dilakukan di kotak-kotak 4.5, q.6. r.5 dan r.6, menunjukkan adanya sisa-sisa gapura yang menuju ke kompleks pendapa (gambar 2).

Hipotesa lain yang dapat dikemukakan dari data yang ada adalah mengenai sistem pengerjaan batu di Kraton Ratu Baka yang mungkin dilakukan secara borongan. Dengan pengertian masing-masing pemborong mengerjakan sejumlah batu dengan bentuk yang telah ditentukan. Akan tetapi setelah dipasang ternyata terjadi perubahan-perubahan. Scbagai contoh : bagian bawah batu payon atap pagar, semula diberi pengait, tetapi setelah dipasang di atas dorpel, ternyata pen pengait tersebut tidak diperlukan lagi. sehingga harus dipotong karena di pinggir-pinggir dorpel telah diberi pengait, schingga payon tersebut tidak dapat bergeser ke arah lain. Hal Serupa mungkin terjadi pada lapisan batu lantai di atas batu pagar l. Meskipun batu pagar l bagian atasnya mempunyai lubang. namun di at asnya hanya dipasang batu lantai yang rata dan tidak bertakik. 
Demikianlah sekelumit data yang diperoleh dari hasil pengamatan serta penelitian data bangunan sebelum dan selama pemugaran berlangsung. Mudah-mudahan uraian yang serba terbatas ini akan dapat membuka jalan untuk penelitian lanjut terhadap kekunaan di kompleks Ratu Baka.

K e pus t a $k$ a a n

Casparis, J.G. de, Prasasti Indonesia II, Dinas Purbakala R.I. 1956, Bandung : Masa B Aru, hlm. 280 - 330.

, "New evidence on cultural relations betwen Java and Ceylon in Ancient times", Artibus Aslae, Vol. XXIV 3/4, 1961, Switzerland, Artibus A siae-Publishers, hlm. 241 - 248.

Dinas Purbakala R.I., Laporan Tahun 1951 - 1952, Jakarta : 1958, hlm. $11-13$.

Kempers, A.J. Bernet, AMERTA 1. Dinas Purbakala R.1. 1952, hlm. 43-49

Krom, N.J., Inleiding tot de Hindoe-Javaansche kunst. I. 'S-Gravenhage Martinus Nijhoff, 1923, hlm. 244 - 246.

Slamet Pinardi, Laporan Arkeologi Pemugaran Kraton Ratu Boko 1978 1980, jProyek Pemugaran Dan Pemeliharan Peninggalan Sejarah dan Purbakala D.I.Y. (belum diterbitkan).

Teguh Asmar - Bennet Bronson, Laporan Ekskavasi Ratu Baka 1973. Lembaga Purbakala Dan Peninggalan Nasional - The University of Pennsylvania Museum. 


\section{Beberapa jenis tanda goresan}

pada batu lantai dan pagar I (di bawah lantai sekarang)

Sisi utara : (sayap timur gapura utara).

$$
\begin{aligned}
& 1=1 \\
& 2=1 \\
& 3== \\
& 4=- \\
& 5=+ \\
& 6== \\
& 7=1 \\
& 8=- \\
& 9=4 \\
& 10=\oplus \\
& 11=1
\end{aligned}
$$$$
12=1
$$$$
13=1
$$$$
14=11
$$$$
15=11
$$$$
16=111
$$$$
17=111
$$$$
18=11
$$$$
19=1
$$$$
20=x
$$$$
21=x
$$$$
22=x
$$

$$
\begin{aligned}
& 23=\varnothing \\
& 24=x \\
& 25=-\lambda \\
& 26=レ \\
& 27=+\pi \\
& 28=1 \\
& 29=- \\
& 30=\nearrow \\
& 31=\nearrow \\
& 32=4 \\
& 33=\pi \\
& 34=レ
\end{aligned}
$$

Sisi atas : (sayap timur gapura utara)

$$
\begin{array}{ll}
35=t & 42=t \\
36=+ & 43=\uparrow \\
37=t & 44=t \\
38=+ & 45=t \\
39=1 & 46=1 \\
40=x & 47=+ \\
41=+ & 48=t
\end{array}
$$

Sisi utara : (sayap barat gapura utara)

$$
\begin{aligned}
& 49=\equiv \equiv 1 \\
& 52=11 \\
& 53=\triangle \\
& 50=+ \\
& 54=T \text { 员 } \\
& 51=1 \\
& 55=\Delta \Delta \\
& \begin{array}{l}
56=\mid x \\
57=\left.x\right|^{x} \\
58=11 \\
59=11
\end{array}
\end{aligned}
$$




\section{pada batu-batu di kompleks pendapa Kraton Ratu Baka}
$1=\underline{1}$
$9=\wedge$
$17=)($
$25=$ )
$2=L$
$10=$
$3=7 E$
$11= \pm$
$18=I$
$26=V$
$4=V$
$12=\wedge$
$19=x$
$27=1-1$
$5=r$
$13=r$
$20=T$
$28=|v|$
$6=\wedge$
$14=\pi$
$7=\smile$
$15=\sqcap$
$21=V$
$29=$ (I)
$8=\top$
$16=\wedge$
$22=\backsim$
$30=\lambda$
$23=-s$
$31=$ 令
24 = '
$32=\perp$
$33=$
$34=T$
$35=()$
$42=m$
$36=L$
$43=ハ$
$49=-r$
$37=4$
$44=\Psi$
$50=1)$
$38=1$
$45=\smile$
$39=\langle\rangle$
$46=U$
$51=-$
$52=2$
$40=\lambda$
$47=H$
$41=$ ( )
$48=K$
$53=-1$
$54=$ ( )
$55=$
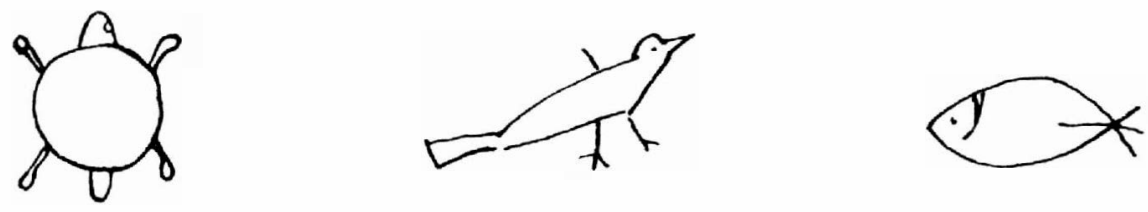


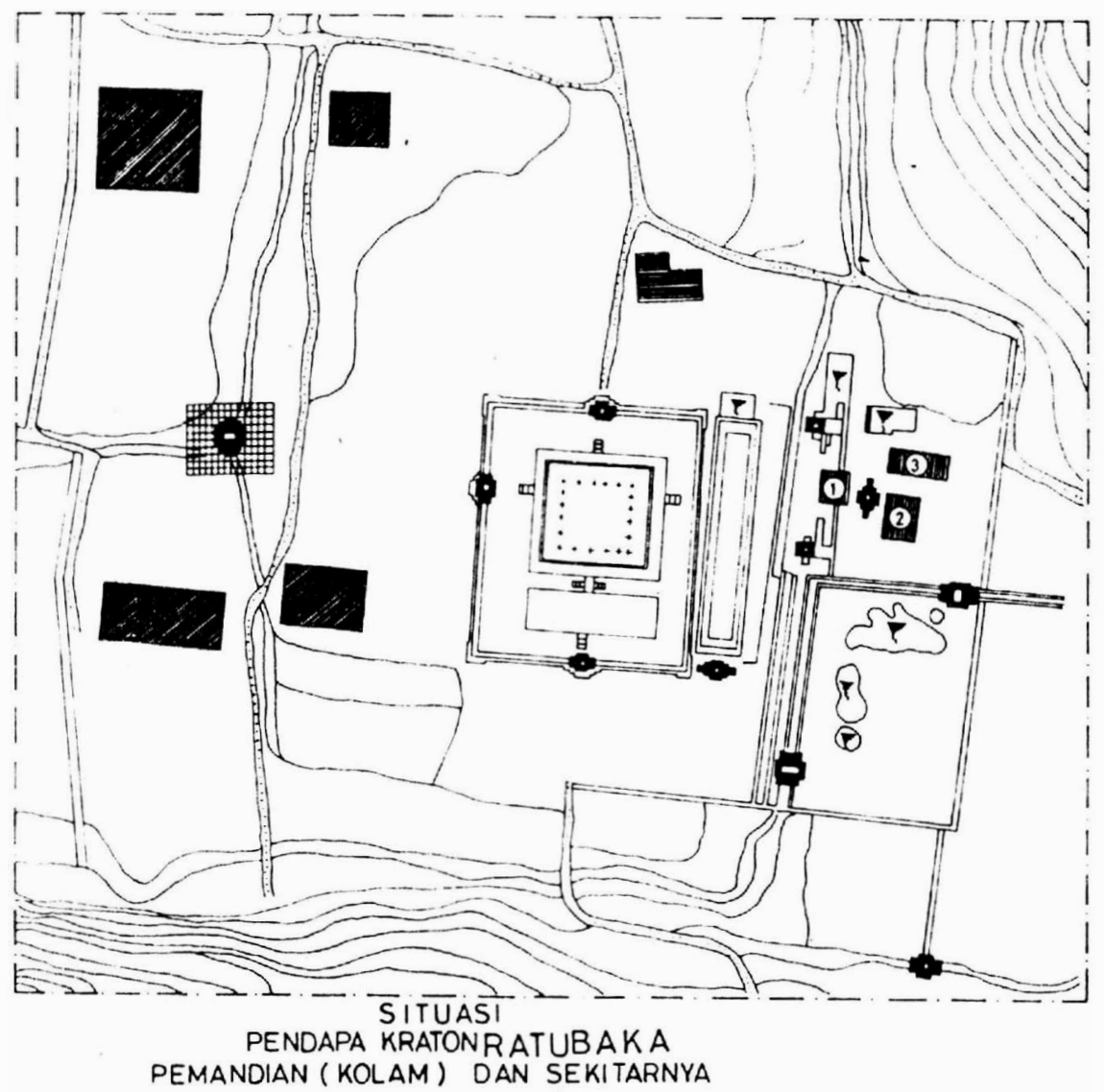

Peta situasi pendapa Kraton Ratu Baka dan sekitarnya (sumber : Proyek Pemugaran dan Pemeliharaan Peninggalan Sejarah dan Purbakala DIY). 


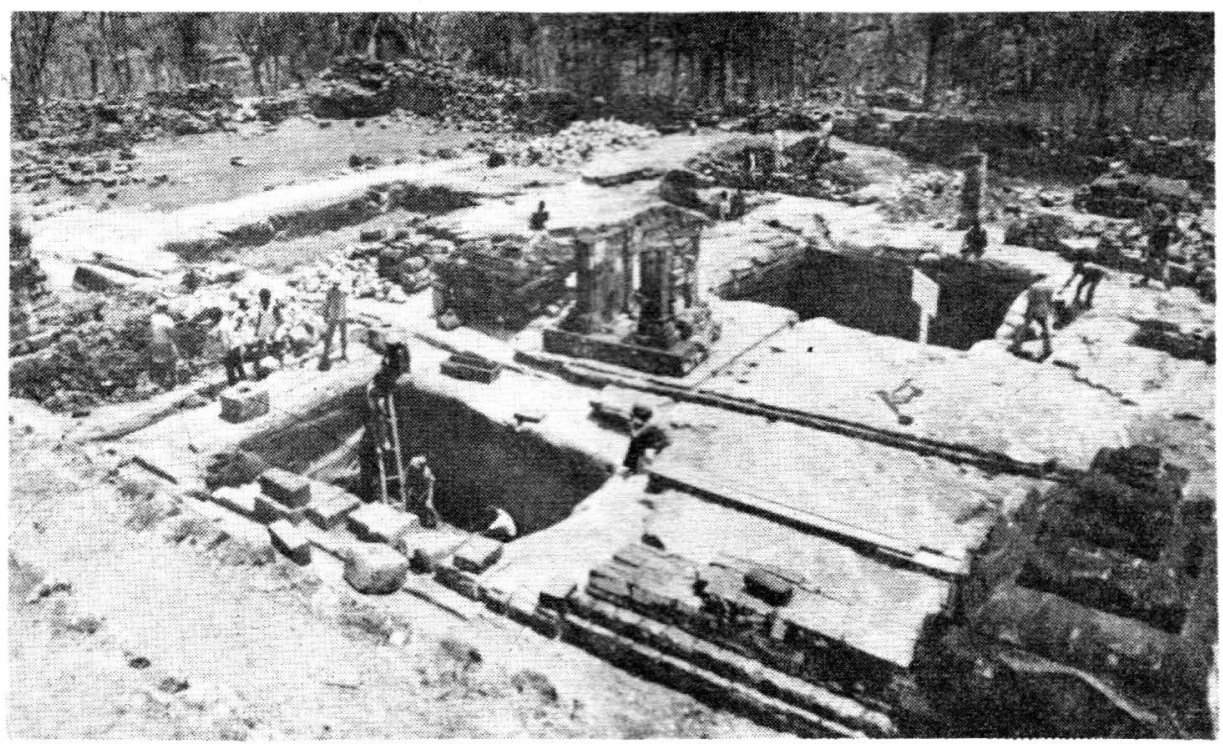

Kompleks kolam sewaktu dilakukan pembersihan.

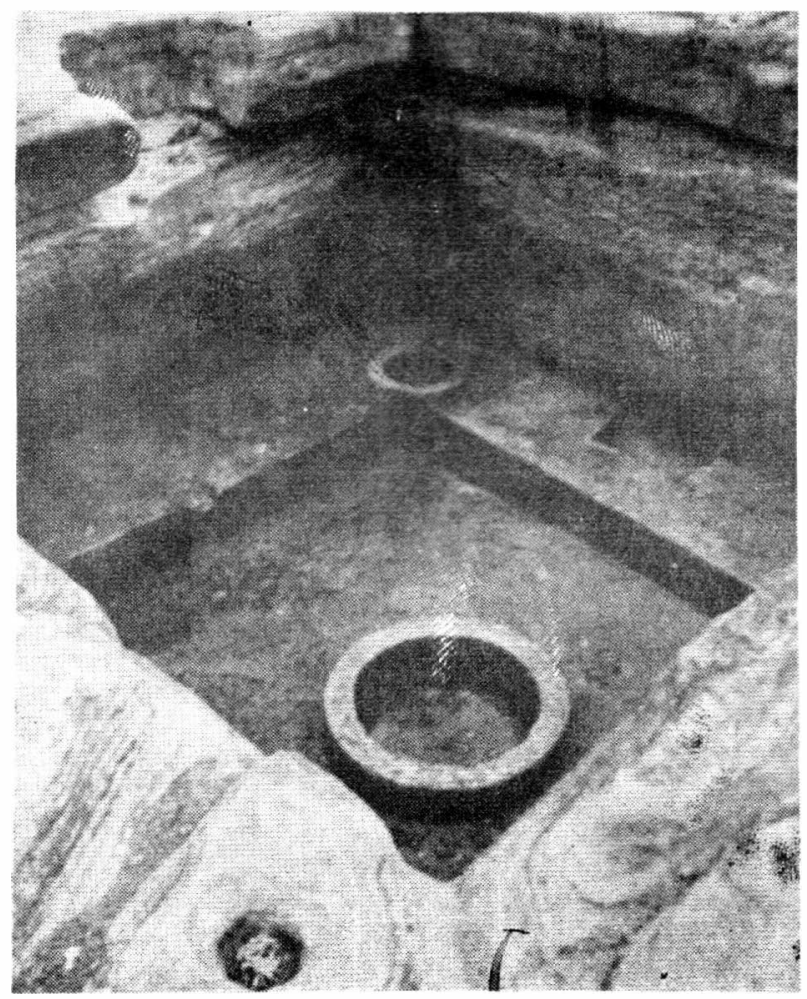

Salah satu dasar kolam setelah dibersihkan. 


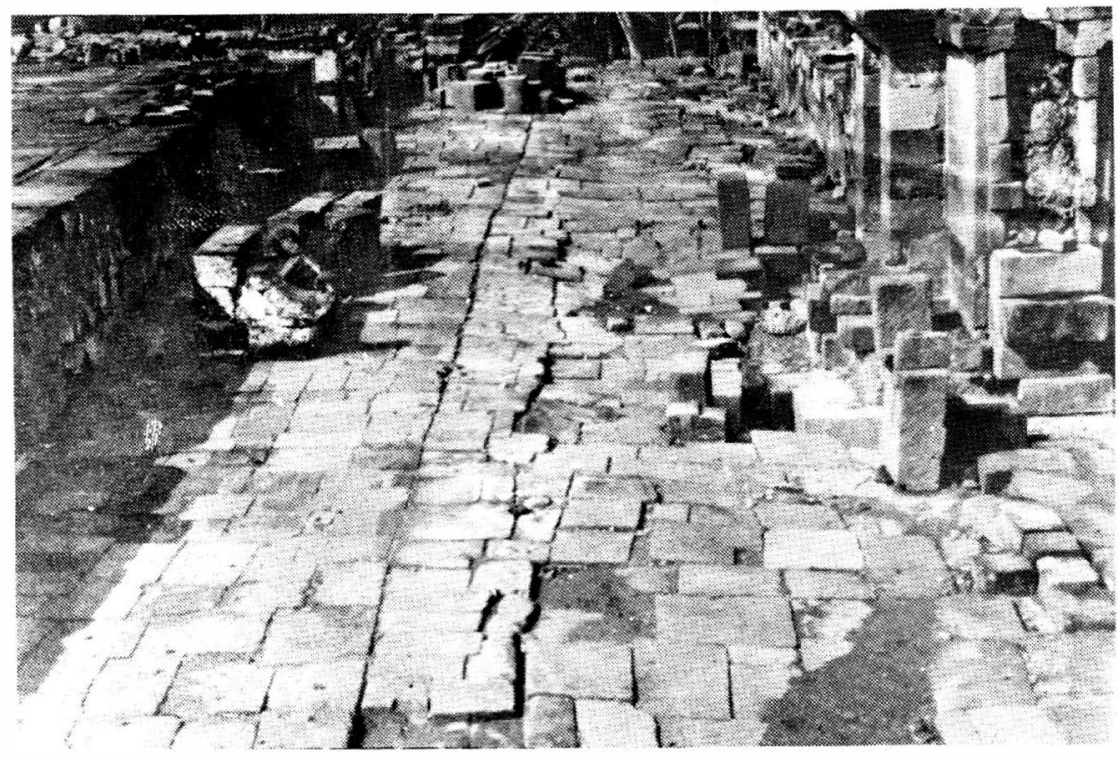

Keadaan lantai sisi barat pendapa sebelum dipugar.

Garis lurus di lantai merupakan batas pagar I.

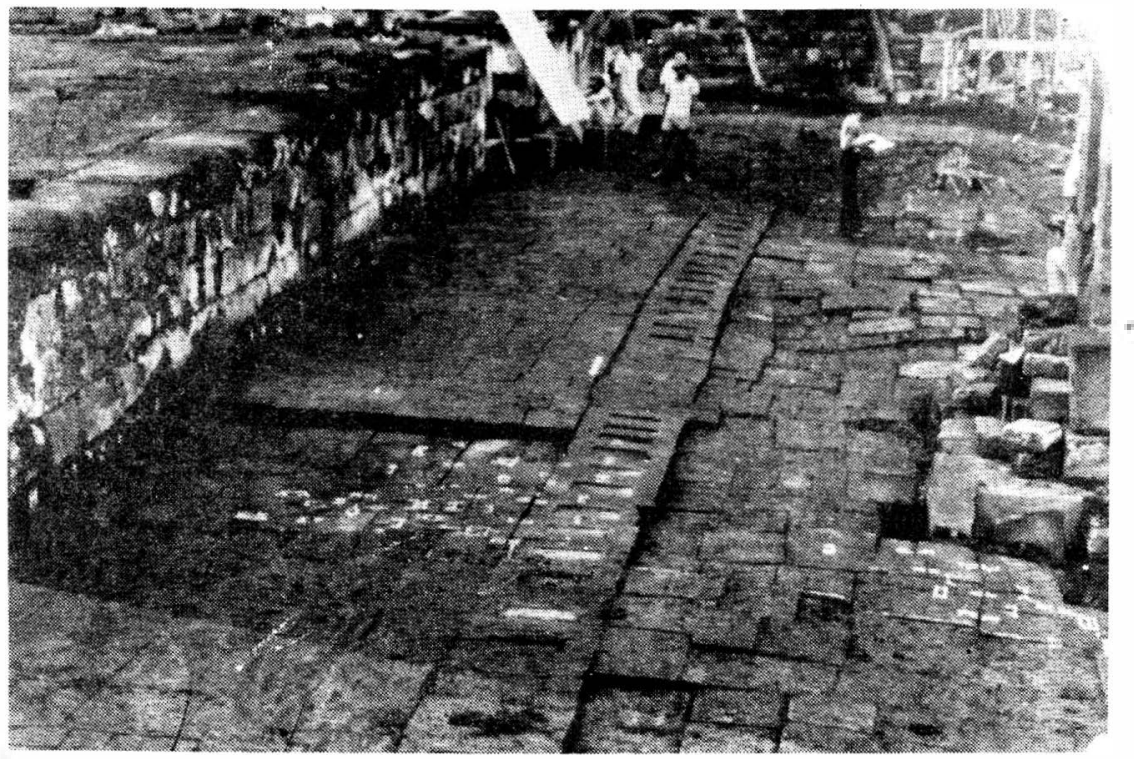

